\title{
Cellular Porous Brick-A Novel Permeable Pavement Strategy
}

\author{
Shiguang Chen*, Yu Zhang, Liangyang Qiu, Xiaobing Xu, \\ Didong Lin, Lin Chen, Jinchi Lin, Hengwei He \\ College of Urban and Rural Construction, Zhongkai University of Agriculture and Engineering, Guangzhou, China \\ Email: *luyi813929@163.com
}

How to cite this paper: Chen, S.G., Zhang, Y., Qiu, L.Y., Xu, X.B., Lin, D.D., Chen, L., Lin, J.C. and He, H.W. (2020) Cellular Porous Brick-A Novel Permeable Pavement Strategy. Natural Resources, 11, 543-553. https://doi.org/10.4236/nr.2020.1112032

Received: October 10, 2020

Accepted: December 4, 2020

Published: December 7, 2020

Copyright ( 2020 by author(s) and Scientific Research Publishing Inc. This work is licensed under the Creative Commons Attribution International License (CC BY 4.0).

http://creativecommons.org/licenses/by/4.0/

\section{(c) (i) Open Access}

\begin{abstract}
Permeable pavement is generally considered as one of the most effective practices of rainwater management. This paper analyses the defects of current permeable pavement. Inspired by the honeycomb bionic structure which has superior mechanical properties and structural efficiency, an innovative "honeycomb-like" model of permeable brick measuring $190 \times 100 \times 60 \mathrm{~mm}$ in size was proposed and constructed. The mechanical strength and permeability performance of the honeycomb permeable brick were experimentally assessed by universal testing machine and artificial rainfall equipment, respectively. Experiment results demonstrated an excellent performance in compressive tolerance and permeability. The critical damage load $(\mathrm{Fc})$ and compressive strength (Ec) of honeycomb brick were $336.46 \mathrm{KN}$ and $17.70 \mathrm{MPa}$, which were $18.06 \%$ and $11.04 \%$ higher than that of ordinary solid permeable bricks, respectively, compared with the conventional permeable bricks. The honeycomb brick is capable of increasing the permeability coefficient by $19.2 \%$ and $11.96 \%$ under rainfall repetition period of 20 and 30 years respectively. These results demonstrated that the permeable brick with honeycomb-like structure can provide a new paving strategy for the construction of sponge city.
\end{abstract}

\section{Keywords}

Permeable Pavement, Honeycomb Structure, Mechanical Properties, Permeability

\section{Introduction}

Rapid urban expansion in many cities has resulted in that vegetation cover was replaced with impervious surfaces for the construction of buildings and associated infrastructure [1] [2] [3]. The diminishing of permeable coverage in urban 
area, especially in rain-rich region such as south china, may frequently cause vast runoff of storm-water in summer [4].

Urban water-related issues have raised concerns worldwide among scientific communities, and water management is an essential aspect in the sustainable development of urban areas [5] [6]. A larger number of solutions have been suggested to address water problems for urban areas including the best management practices (BMPs) in the United States [7], sustainable urban drainage systems (SUDS) in the United Kingdom [8], the low impact development (LID) strategy in New Zealand as well [9], water sensitive city (WSC) or water sensitive urban design (WSUD) in Australia [10]. All of these novel concepts and strategies were aimed at preserving and maintaining the natural drainage runoff profile as much as possible [11] [12].

For developing countries like China, most urban areas have witnessed high population growth, intensive expansion of impermeable roads and rooftops [13]. In order to alleviate urban water-related problems, the urban water management strategy name as "sponge city" has been implemented as an adaptation measure to address urban water issues in China since 2013 [14]. It emerges that Sponge City has four main principles; these are: urban water resourcing, ecological water management, green infrastructures, and urban permeable pavement [15]. Among the above Sponge City strategies, many studies have found that the performance of permeable pavements in terms of flooding reduction was even better and more effective than other Sponge City technologies, including green roofs or rainwater resourcing [16] [17].

There are four main types of infiltration pavements: permeable concretes, permeable asphalts, grass pavement, and permeable interlocking concrete pavers available in current market [18]. However, these permeable pavements, have common disadvantage that cannot achieve the combination of pervious and structural strength. The permeability of permeable pavement, is greatly affected by the porosity, which also has an significant inverse relationship with the structural strength. Therefore, how to improve the capacity of permeability under the premise of not reducing the bearing capacity and structural strength of the road and square has become one of the technical barriers in urban sponge transformation.

Extensive great inventions originated from the imitation of nature in human history. Due to its superior mechanical properties and structural efficiency, honeycomb structure has been widely used in chemical industry, aerospace, national defense and other fields [19]. However, despite that honeycomb structure has excellent mechanical properties and permeability, research has mainly focused on permeable concrete, permeable asphalt, or open-graded asphalt concrete mixture, etc. In the design of permeable pavement or in the construction of sponge city, there are to date no studies concerning the attempts and practices of applying the honeycomb structure in permeable pavement, and there is no concept of "honeycomb-like" sandwich structure proposed in domestic and abroad. 
Therefore, the objective of this study is to assess the potential application foreground of honeycomb structures in the sponge transformation of urban hardened ground such as roads, squares, parking lots, and urban site walkways. A novel honeycomb-like permeable brick was designed and mechanical properties of which were tested by laboratory experiment. The performance in term of bearing capacity, permeability, cost and manufacturing process between honeycomb bricks and conventional permeable concrete bricks were also compared in this study.

\section{Materials and Methods}

This section presents the raw materials used in this experiment, the manufacturing process of honeycomb permeable brick, as well as the test and analysis methods used in this project.

\subsection{Raw Material}

Cement (P.C32.5R) was purchased from Sichuan Xing Chuan Cheng Cement Co., Ltd. Concrete early strength agent (DC-C13) was supplied by Beijing Dechang Weiye Construction Engineering Technology Co., Ltd. Coarse aggregate (3 - $5 \mathrm{~mm}$ ) and Fine aggregate (bulk river sand) were obtained from Baiyun District, Guangzhou. HJW-30 forced single horizontal shaft concrete mixer was provided by Shanghai Juhong Instrument Equipment Co., Ltd. Resin model was provided by Wuhan Ruyi plexiglass products factory. Honeycomb socket model was designed and manufactured by Shenzhen Jingrui 3D Printing Technology Co., Ltd.

\subsection{Sample Manufacture}

The manufacturing process of honeycomb permeable brick is shown in Figure 1. Concrete was prepared with a proportion of coarse aggregate:fine aggregate:cement:water 20:12:5:3, then poured the mixture into the resin model with hexagon prism and compacted manually after fully mixed. After that, the model was sealed and demoulded after 24 hours, and then placed in a ventilated circumstance for natural drying and waiting for testing.

The materials, models and finished products were shown in Figures 2(a)-(c), respectively. The dimension of honeycomb permeable brick was $190 \times 100 \times 60$ $\mathrm{mm}$ with honeycomb hole of $9 \mathrm{~mm}$ in diameter. The bricks without honeycomb hole were used as the reference and named W-1. Two kinds of bricks made of the same materials.

\subsection{Test Methods and Equipments}

After drying, the main physical parameters such as cell size, density, porosity,

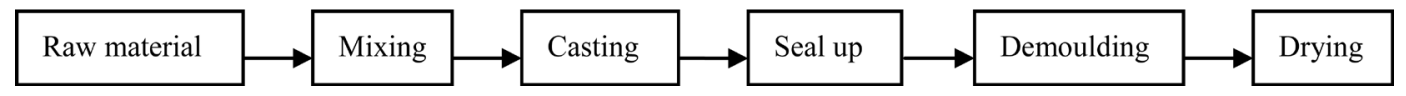

Figure 1. Manufacturing process of honeycomb permeable brick. 
and major mechanical properties as plane compressive strength, shear strength, as well as permeability of the samples were tested during experiment.

\subsubsection{Physical Parameters}

The main physical parameters of honeycomb permeable brick were tested as follows: Density test was determined using the electronic balance (KF-H2 type, Zhejiang Jinhua Kaifeng Group Co., Ltd.) according to ASTM C271 standard [20]. The cell size was measured by vernier caliper according to BMS8-124AB standard.

\subsubsection{Mechanical Properties Test}

The compressive strength and shear strength of honeycomb were tested by electronic universal testing machine (WAKE type electro-hydraulic servo universal testing machine, Guangcai Testing Instrument Co., Ltd.) (Figure 3). The major tested parameters include the maximum bearing capacity $(\mathrm{FBC} / \mathrm{KN})$, yield load $(\mathrm{FSC} / \mathrm{KN})$, maximum compressive strength ( $\sigma \mathrm{BC} / \mathrm{MPA})$, yield limit ( $\sigma \mathrm{SC} / \mathrm{MPA})$ and compressive strength (EC/GPA) of honeycomb along the thickness direction, etc. All aforementioned parameters were tested according to ASTM C365 [21], and ASTM C273 [21] [22].

\subsubsection{Permeability Test}

For permeability coefficient $(\mathrm{mm} / \mathrm{s})$ tests the method outlined in Zhao Fei et al. [23] was adopted. As shown in Figure 4, the artificial rainfall simulation system consists of an artificial rainfall equipment, a test tank, water collection equipment,

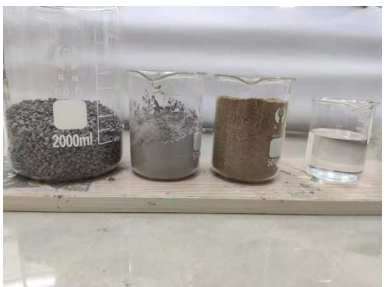

(a)

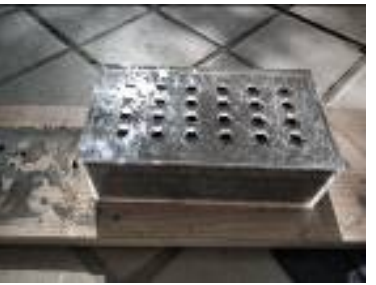

(b)

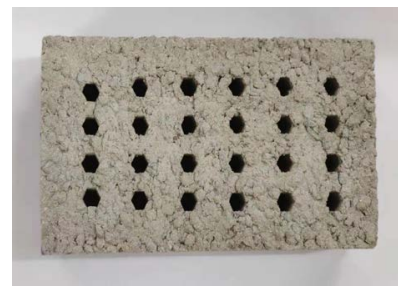

(c)

Figure 2. Materials (a), mould (b) and finished products (c).

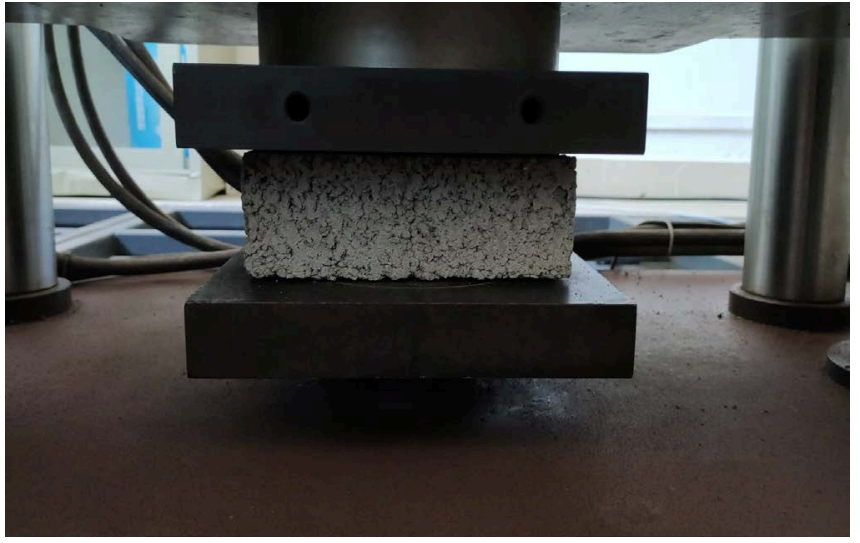

Figure 3. Compression test of electronic universal tester. 


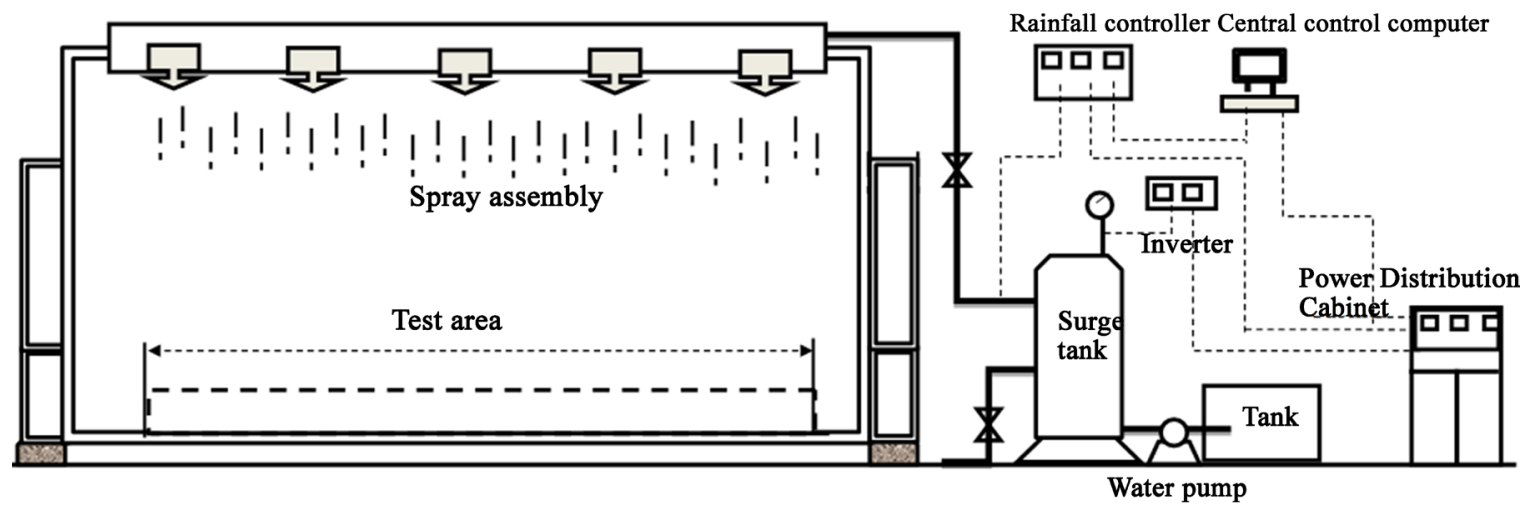

Figure 4. Rainfall model and permeation test.

and control equipment. The principle of superimposed spraying rainfall was adopted, i.e. multiple groups of rainfall sprinklers are arranged in the rainfall coverage area. When each group of sprinklers works alone, it can cause a stable rainfall intensity in the coverage area, while the combination of each group sprinklers can cause different rainfall intensity. The brick samples were placed in the test tank. The rainfall, seepage and rain time were recorded during experiment.

The Permeability coefficient of the Honeycomb brick was tested according to Darcy's law, which was calculated using the following formula:

$$
\Psi_{N, t c}=\frac{P_{N, t c}-W-K_{j} \cdot t_{c}}{P_{N, t c}}
$$

where $\Psi_{N, t c}$ is the runoff coefficient under repetition period of $\mathrm{n}$ years and rainfall duration of $T_{\dot{C}} T_{C}$ is the rainfall duration (min); $P_{N, t c}$ is the rainfall under $N$ years repetition period and $T_{C}(\mathrm{~mm})$ rainfall duration; $W$ is the water capacity of permeable brick $(\mathrm{mm}) ; K_{j}$ is the saturated conductivity of soil base $(\mathrm{mm} / \mathrm{min})$.

\section{Results and Analysis}

The follow sections presented the representative results obtained in current experiment.

\subsection{Physical Parameters of Honeycomb Permeable Brick}

The densities of bricks are inversely related to the porosity, which is also linked to their potential of permeability. As shown in Table 1, the density of sample Y-1 was $2037.37 \mathrm{~kg} / \mathrm{m}^{3}, 3.49 \%$ lower than that of W-1 $\left(2108.42 \mathrm{~kg} / \mathrm{m}^{3}\right)$. The porosity of $\mathrm{Y}-1$ was $22.57 \%, 9.34 \%$ higher than that of W-1 (13.23\%). These observations imply a considerable permeability differences between two samples.

\subsection{Mechanical Properties of Honeycomb Permeable Brick}

Table 2 presents the results of strength tests of two permeable brick samples. It clearly shows that the compressive strength and failure load of W-1 were significantly lower than that of honeycomb brick Y-1. Because the two samples have 
identical sizes, material and process methods, the hexagon honeycomb hole could be the main factor that contributed to the difference of compressive strength and failure load between W-1 and Y-1. As shown in Table 2, the compressive strength of honeycomb permeable brick (Y-1) was 24.21\% higher than that of $\mathrm{W}-1$, which indicated that the bearing capacity of porous brick increased instead of decline with reduced material consumption. Analogously, the failure load of W-1 was $285 \mathrm{KN}$, which was $15.29 \%$ lower than that of Y-1. These results demonstrated that the honeycomb structure has excellent mechanical properties of compression resistance and energy absorption.

It can be seen from Figure 5 that each mechanical index of honeycomb brick is superior to that of solid bricks, e.g. the failure load and cracking load of sample Y-1 are $18.06 \%$ and $11.04 \%$ higher than $\mathrm{W}-1$ respectively. These results suggest a potential linkage between the honeycomb structure and its mechanical properties. As reported in the previous researches, pore structure was able to prevent stress concentration occurred in the plate with arc-shaped hole lattice [19], which was also in accordance with the phenomenon that the arch structure presented more superior compressive strength. Furthermore, as plotted in Figure 5 , the failure load $(\mathrm{Fbc})$ of $\mathrm{Y}-1$ was approximately $6.32 \%$ higher than its cracking load (Fsc), while the failure load of sample W-1 was equal to the cracking

Table 1. Physical parameters of honeycomb permeable brick.

\begin{tabular}{cccc}
\hline Sample No. & Honeycomb hole size/mm & Density $\left(\mathbf{k g} \cdot \mathrm{m}^{3}\right)$ & Porosity (\%) \\
\hline Y-1 & 8.90 & 2037.37 & 22.57 \\
W-1 & - & 2108.42 & 13.23 \\
\hline
\end{tabular}

Table 2. Data sheet of compression experiments.

\begin{tabular}{cccccc}
\hline $\begin{array}{c}\text { Sample } \\
\text { number }\end{array}$ & $\begin{array}{c}\text { Length } \\
(\mathrm{mm})\end{array}$ & $\begin{array}{c}\text { Width } \\
(\mathrm{mm})\end{array}$ & $\begin{array}{c}\text { Compression } \\
\text { area }\left(\mathrm{cm}^{2}\right)\end{array}$ & $\begin{array}{c}\text { Compressive strength } \\
(\mathrm{Rc} / \mathrm{MPa})\end{array}$ & $\begin{array}{c}\text { Failure load } \\
(\mathrm{P} / \mathrm{KN})\end{array}$ \\
\hline Y-1 & 190 & 100 & 19,000 & 17.70 & 336.461 \\
W-1 & 200 & 100 & 20,000 & 14.25 & 285.010 \\
\hline
\end{tabular}

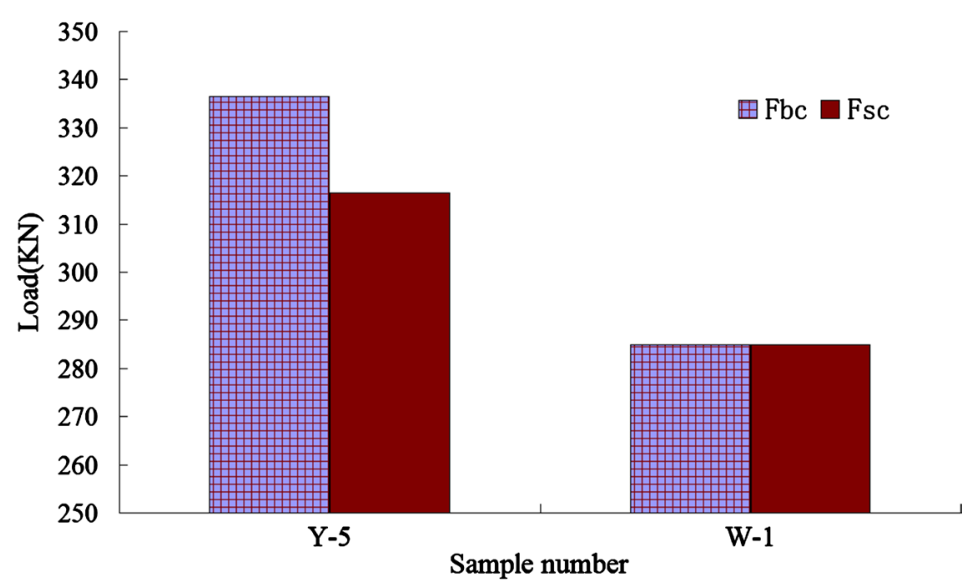

Figure 5. Maximum load (Fbc/KN), yield load (Fsc/KN) of each sample. 
load according to the test results shown in Figure 5. This behaviour can be imputable to the excellent elastic deformation resistance of the honeycomb structure, for which it would not possibly resulting in a collapse to the test block immediately even if the external force exceed the yield limit of honeycomb brick. As documented in previous studies, the deformation of honeycomb structure can be categorized into four stages, they are: elasticity, elastoplasticity, plasticity and compaction [24]. It is hypothesized that even if the honeycomb brick has cracked during the process of compressing, the wall of honeycomb hole may forms a strengthened column, which could effectively prevent the cracks to develop along a specific path [25], thus to delay a structural collapse take place in the brick.

Figure 6 presented the stress deformation curve of honeycomb brick Y-1 and solid brick W-1, respectively. Figure 6(a) shows that the maximum deformation of sample Y-1 was less than $15 \mathrm{~mm}$ when subjected pressure increased from 0 to $145 \mathrm{KN}$. By contrast, the maximum deformation of sample W-1 was higher than $22.5 \mathrm{~mm}$ under pressure ranged from 0 to $90 \mathrm{KN}$ (seen Figure 6(b)). It was obviously that, as compared to solid brick, smaller deformation occurred in the honeycomb brick when bearing identical pressure.

It can be seen from Figure 6, the sample of Y-1 presented a continuous and stable deformation curve under stress during the whole test period. In contrast, $\mathrm{W}-1$ undergones two severe deformations under load of $18 \mathrm{KN}$ and $82 \mathrm{KN}$ respectively. These behaviours were mainly attributed to the unique porous structure of honeycomb brick. On the one hand, the honeycomb unit was able to effectively buffer the radial external force (lateral force), thus lead to a smaller
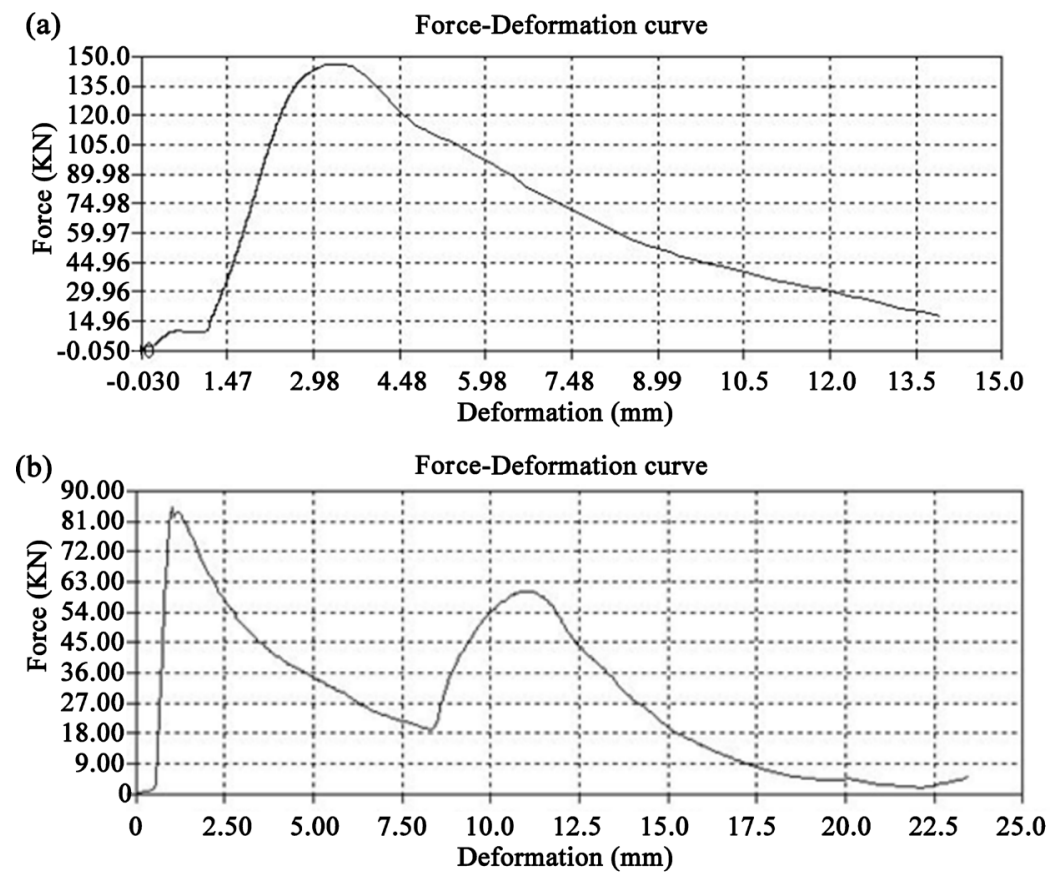

Figure 6. Stress-deformation curves of honeycomb bricks (a) and conventional bricks (b). (a) Y-1; (b) W-1. 
stress and deformation. On the other hand, as the honeycomb unit can acts as a spring to buffer the radial force (lateral force), thereby allow most of the deformation and stress concentrated in several honeycomb cells adjacent to the bearing point of external force, thus leading to a reduced stress and deformation for other parts of the bricks [26].

\subsection{Permeability}

Figure 7 shows the permeability of two samples. Permeability coefficient is often used as a technical index to evaluate the infiltration performance of permeable pavement [27]. As can be seen from Figure 7, the permeability coefficient of honeycomb brick (Y-1) was $5.72 \mathrm{~mm} / \mathrm{s}$ under P20 (a designed rainfall repetition period of 20 years), and was $6.74 \mathrm{~mm} / \mathrm{s}$ under P30, which was $19.2 \%$ and $11.96 \%$ higher than that of solid-brick $(4.80 \mathrm{~mm} / \mathrm{s}$ and $6.02 \mathrm{~mm} / \mathrm{s}$ under P20 and P30, respectively). The design of porous structure in the honeycomb brick, leading to a higher porosity of the pavement, as a consequence, contributes to the improvement of permeability.

\subsection{Comparison with Traditional Permeable Brick}

As can be seen from Table 3, the porous honeycomb has significant advantages in terms of compressive strength, shear resistance, porosity and permeability in comparison to several conventional permeable pavements. The excellent performance of honeycomb brick in compressive strength and flexural (shear) strength, were mainly due to its porous structure, which could more effectively to diffuse pressure stress and anti-deformation [26]. As a result of the internal porous structure, leading to a higher porosity of the brick, would also contribute to the enhancement of permeability.

In addition, honeycomb brick has significant advantages in cost, which is linked to its porosity structures that substantial reduced consumption of material. As reported in Table 3, the manufacturing processes of the honeycomb brick are uncomplicated in comparison to permeable concrete, permeable asphalt, and sintered brick.

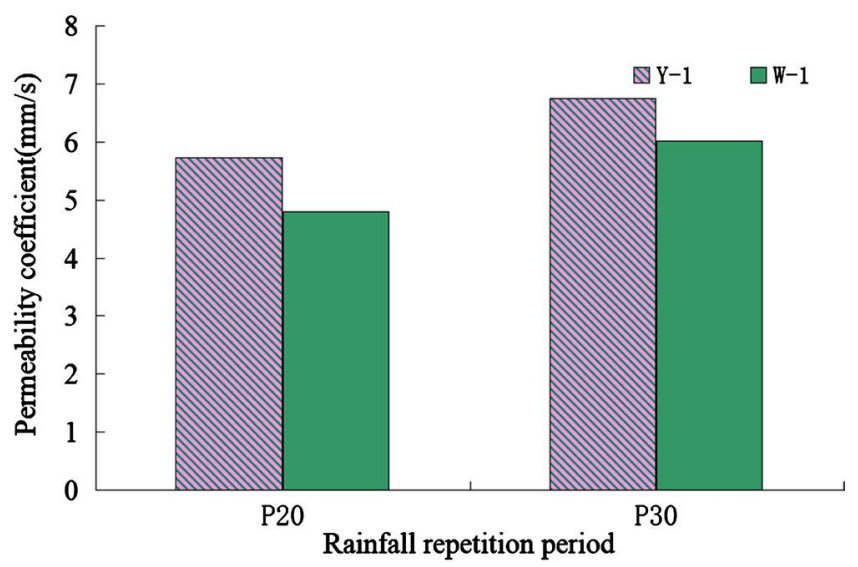

Figure 7. Permeability coefficients of two samples. 
Table 3. Comparison of raw materials, manufacturing methods, technical indexes and application scope of several kinds of permeable bricks.

\begin{tabular}{|c|c|c|c|c|c|}
\hline \multicolumn{2}{|l|}{ Classification } & Permeable concrete & Porous Asphalt & Sintered permeable brick & Porous honeycomb brick \\
\hline \multicolumn{2}{|l|}{ Raw material } & $\begin{array}{l}\text { Cement, continuous } \\
\text { graded aggregate }\end{array}$ & $\begin{array}{l}\text { Single graded aggregate, } \\
\text { asphalt }\end{array}$ & $\begin{array}{l}\text { Inorganic nonmetallic } \\
\text { materials }\end{array}$ & $\begin{array}{l}\text { Continuous graded } \\
\text { aggregate, cement }\end{array}$ \\
\hline \multicolumn{2}{|l|}{$\begin{array}{l}\text { Manufacturin } \\
\text { g methods }\end{array}$} & $\begin{array}{l}\text { Mixing-stirring- } \\
\text { compaction }\end{array}$ & $\begin{array}{l}\text { Mixing-stirring- } \\
\text { compaction }\end{array}$ & Shaping-Fired & $\begin{array}{l}\text { Mixing-stirring- } \\
\text { compaction }\end{array}$ \\
\hline \multirow[t]{4}{*}{ Performance } & $\begin{array}{l}\text { Compressive } \\
\text { strength/MPa }\end{array}$ & $15-30$ & $15-30$ & $25-35$ & $15.15-23.22$ \\
\hline & $\begin{array}{l}\text { Flexural } \\
\text { Strength/MPa }\end{array}$ & $3.0-5.0$ & $3.0-5.0$ & $4.5-6.0$ & $8-11$ \\
\hline & Porosity \% & $10-25$ & $10-25$ & $15-20$ & $16.2-22.6$ \\
\hline & $\begin{array}{l}\text { Permeability } \\
\text { coefficient } / \mathrm{mm} / \mathrm{s}\end{array}$ & $1.0-10.0$ & $1.0-10.0$ & $1.0-15.0$ & $5.72-9.26$ \\
\hline $\begin{array}{l}\text { Cost and } \\
\text { applicability }\end{array}$ & & $\begin{array}{l}\text { High temperature and } \\
\text { humidity resistance, low } \\
\text { strength }\end{array}$ & $\begin{array}{l}\text { High strength, low } \\
\text { temperature and humidity } \\
\text { resistant }\end{array}$ & High abrasion resistant & $\begin{array}{l}\text { High strength, high } \\
\text { permeability coefficient } \\
\text { and low cost }\end{array}$ \\
\hline
\end{tabular}

Data cited from references [1] and [2].

\section{Conclusion}

In this study, an innovative "honeycomb-like" permeable brick was proposed and the mechanical strength and permeability performance of this novel honeycomb permeable brick were assessed. The experiment results confirmed that the honeycomb porous permeable brick has superior compressive strength and permeability in comparison to the conventional permeable pavements. The compressive strength and failure load of honeycomb brick were $24.2 \%$ and $18.1 \%$ higher than that of solid brick respectively, and the permeability was $19.2 \%-53.8 \%$ higher than that of solid-brick. This study provided new methods for the sponge transformation of urban hardened ground, such as city square and pedestrian street.

\section{Acknowledgements}

This study was funded by the 2018 National innovation training program for college students, China: Sponge transformation strategy of urban hard ground based on honeycomb bionics (201811347014). We wish to thank the staff of laboratory, Zhongkai University of Agriculture and Engineering, for the convenience of this experiment. We also thank Zhuo-Xianrong, professor of the Zhongkai University of Agriculture and Engineering, for providing valuable suggestions and manuscript revision.

\section{Conflicts of Interest}

The authors declare no conflicts of interest regarding the publication of this paper. 


\section{References}

[1] Zhang, X., Hu, M., Chen, G. and Xu, Y. (2012) Urban Rainwater Utilization and its Role in Mitigating Urban Waterlogging Problems-A Case Study in Nanjing, China. Water Resources Management, 26, 3757-3766. https://doi.org/10.1007/s11269-012-0101-6

[2] Xia, W. (2013) The Cause Analysis and Countermeasures of Waterlogging in Wuhan. Applied Mechanics and Materials, 357-360, 1962-1965.

https://doi.org/10.4028/www.scientific.net/AMM.357-360.1962

[3] Li, Y., Huang, Y.Y., Ye, Q.L., Zhang, W.L., Meng, F.G. and Zhang, S.X. (2018) Multi-Objective Optimization Integrated with Life Cycle Assessment for Rainwater Harvesting Systems. Journal of Hydrology, 558, 659-666. https://doi.org/10.1016/j.jhydrol.2018.02.007

[4] Kam, C.D.G. (2017) Recycling and Reuse of Rainwater and Stormwater. Encyclopedia of Sustainable Technologies, 4, 69-76. https://doi.org/10.1016/B978-0-12-409548-9.10169-1

[5] Marlow, D.R., Moglia, M., Cook, S. and Beale, D.J. (2013) Towards Sustainable Urban Water Management: A Critical Reassessment. Water Research, 47, 7150-7161.

[6] Schaffer, D. and Vollmer, D. (2010) Pathways to Urban Sustainability: Research and Development on Urban Systems, National Research Council of the National Academies. The National Acadmies Press, Wahington DC, 1-124.

[7] Fletcher, T.D., Shuster, W., Hunt, W.F., Ashley, R., Butler, D., Arthur, S., Trowsdale, S., et al. (2014) The Evolution and Application of Terminology Surrounding Urban Drainage. Urban Water Journal, 12, 525-542. https://doi.org/10.1080/1573062X.2014.916314

[8] Scholz, M. (2006) Best Management Practice: A Sustainable Urban Drainage System Management Case Study. Water International, 31, 310-319. https://doi.org/10.1080/02508060608691934

[9] Chui, T.F.M., Liu, X. and Zhan, W.T. (2016) Assessing Cost-Effectiveness of Specific LID Practice Designs in Response to Large Storm Events. Journal of Hydrology, 533, 353-364. https://doi.org/10.1016/j.jhydrol.2015.12.011

[10] Mao, X.H., Jia, H.F. and Yu, S.L. (2017) Assessing the Ecological Benefits of Aggregate LID-BMPs through Modelling. Ecological Modelling, 353, 139-149. https://doi.org/10.1016/j.ecolmodel.2016.10.018

[11] Brown, R.R., Keath, N. and Wong, T.H.F. (2009) Urban Water Management in Cities: Historical, Current and Future Regimes. Water Science \& Technology, 59, 847-855. https://doi.org/10.2166/wst.2009.029

[12] Ashley, R., Lundy, L., Ward, S., Shaffer, P., Walker, L., Morgan, C., Saul, A., Wong, T. and Moore, S. (2013) Water-Sensitive Urban Design: Opportunities for the UK. Proceedings of the Institution of Civil Engineers-Municipal Engineer, 166, 65-76. https://doi.org/10.1680/muen.12.00046

[13] Chan, F.K.S., Griffiths, J.A., Higgitt, D., Xu, S., Zhu, F., Tang, Y.-T., Xu, Y. and Thorne, C.R. (2018) "Sponge City" in China-A Breakthrough of Planning and Flood Risk Management in the Urban Context. Land Use Policy, 76, 772-778. https://doi.org/10.1016/j.landusepol.2018.03.005

[14] Lin, C.-C., Liou, K.-Y. and Lee, M. (2019) Impacts of Urban Water Consumption under Climate Change: An Adaptation Measure of Rainwater Harvesting System, Journal of Hydrology, 572, 160-168.

[15] Thuy Nguyen, T., Hao Ngo, H., Guo, W.S., Wang, X.C.C., Ren, N.Q., Li, G.B., Ding, 
J. and Liang, H. (2019) Implementation of a Specific Urban Water Management-Sponge City. Science of the Total Environment, 652, 147-162. https://doi.org/10.1016/j.scitotenv.2018.10.168

[16] Damodaram, C., Giacomoni, M.H., Prakash Khedun, C., Holmes, H., Ryan, A., Saour, W. and Zechman, E.M. (2010) Simulation of Combined Best Management Practices and Low Impact Development for Sustainable Stormwater Management. Journal of the American Water Resources Association, 46, 907-918. https://doi.org/10.1111/j.1752-1688.2010.00462.x

[17] Hu, M., Zhang, X., Siu, Y., Li, Y., Tanaka, K., Yang, H. and Xu, Y. (2018) Flood Mitigation by Permeable Pavements in Chinese Sponge City Construction. Water, 10, 172. https://doi.org/10.3390/w10020172

[18] Woods Ballard, B., Wilson, S., Udale-Clarke, H., Illman, S., Scott, T., Ashley, R. and Kellagher, R. (2015) The SuDS Manual. C753 CIRIA, CIRIA, London.

[19] Zhou, M., Xie, J., Chen, J.X., Liu, C. and Tuo, W.Y. (2015) The Influence of Processing Holes on the Flexural Properties of Biomimetic Integrated Honeycomb Plates. Materials \& Design, 86, 404-410. https://doi.org/10.1016/j.matdes.2015.07.060

[20] American Society for Testing and Materials (2016) Standard Test Method for Density of Sandwich Core Meterial. 2016 Edition, ASTM International Press, Pennsylvania, 1-4.

[21] American Society for Testing and Materials (2016) Standard Test Method for Flatwise Compressive Properties of Sandwich Cores. ASTM International Press, Pennsylvania, 1-4.

[22] American Society for Testing and Materials (2016) Standard Test Method for Shear Properties of Sandwich Core Meterials. ASTM International (ASTM) Press, Pennsylvania, $1-4$.

[23] Zhao, F., Zhang, S.H., Chen J.G., et al. (2011) Study on Rainwater Infiltration Collection and Runoff Reduction Technology for Permeable Pavement. Water \& Wastewater Engineering, 37, 254-258.

[24] Chen, J.X., He, C.L., Gu, C.L., Liu, J.X., M., C.W. and Guo, S.J. (2014) Compressive and Flexural Properties of Biomimetic Integrated Honeycomb Plates. Materials \& Design, 64, 214-220. https://doi.org/10.1016/j.matdes.2014.07.021

[25] Zhou, L.Y., Wu, M.C. and He, H.Z. (2016) Research of Plastic Honeycomb Sandwich Plates' Bending Stiffness by Finite Element Method. Plastic, 45, 78-80.

[26] Dong,Y.J. and Zhu, G.W. (2016) Mechanical Analysis and Bionic Structure Design of Astronautic Payloads Based on Natural Honeycomb. Journal of Astronautics, 37, 262-267.

[27] Chen, S.F., Wang, H.L., Yang, W.Z. and Zhang, D.X. (2012) Research on City Energy Conservation Basing Rainwater Utilization. Procedia Environmental Sciences, 12, 72-78. https://doi.org/10.1016/j.proenv.2012.01.249 